\title{
Ethics and Accountability in Nigerian Public Service: Its Collapse and the Way Forward
}

\author{
Muhammad Abdullahi \\ Department Of Public Administration \\ Federal Polytechnic Kaura Namoda \\ Zamfara State, Nigeria
}

Doi:10.5901/ajis.2012.v2n5p117

Abstract

This paper seeks to assess the ethics and accountability within which the public service in Nigeria operate since independence through the focus on accountability and control measures specifically designed to guard against abuse and misuse of bureaucratic power. It argues that these measures have failed to provide the service with the necessary ethical environment in the post independence period due to deliberate frustration by civil servants and the government hence resulting in unethical conducts, unbridle corruption and collapse of public service. The paper concludes that the only way to tackle unethical conduct in the public service is to tackle corruption at all level of the public service and expose it. Since the various control and accountability measure instituted in the constitution have been rendered in operative by the same people who are expected to work by them. The paper recommend that the public servant should be aware of the ethical values and standards as outlined in the civil service rules (CSR), political will to enforce those standards.

Key words: Ethics, accountability, Nigeria, bureaucracy, public service.

\section{Introduction}

There are some internal mechanism and control measures in place to ensure that the public service conduct its business within some ethical parameters. These internal mechanisms not only provide an ethical environment within which the public service is expected to perform it responsibilities but also act as a form of accountability measures for the service. These are the Civil Service Rules (CSR) which replaced the general orders bequeathed to the service by the colonials and the civil service Hand book. The civil service rules is the ground norm for service conduct and it covers from appointment to separation from the service, discipline salary, leave and reward for performance.

The civil service hand book acts as a reference book and guide for all levels of personnel in the service. the scope of the hand book is quiet exhaustive, dealing with all salient features of the service, the role of the civil servant in government and the manner in which government business should be conducted in order to have an efficient and effective administrative system capable of winning public confidence in a chapter titled code of ethics in government business, the values of discipline, loyalty, honesty, courage, courtesy, cooperation, tact, industry, honesty, courage, courtesy, cooperation, tact, industry, fairness and equity were emphasized. In a bid to have an ethically upright and accountable public service the hand book and the CSR are further complemented by the following documents the guidelines for appointment, promotion and discipline issued by the civil service commission, the code of conduct bureau whose mandate covers behavior of both political and public servants alike. The fifth schedule of the 1999 federal constitution which contains codes to guide the conduct of officials with emphasis placed on how to avoid conflict of interests and finally the code of conduct tribunal whose responsibility is to bring to trial or prosecute all cases of infringement or non - compliance of the ethics governing the conduct of government business. 


\section{The Collapse of Ethics and Accountability in the Nigerian Public Service}

It is interesting that inspite of all these control measures put in place to ensure an ethical Nigerian public service system, the bureaucratic ethics has been abandoned and act of corruption has become the norm. outright corruption, tribalism, nepotism embezzlement, influence peddling, unprofessionalism, use of position for self enrichment, bureaucratic bullying, excessive centralization, multiplication of agencies, partiality, dejected and denounced behaviors like moonlighting absenteeism , lateness to work, among other vices are now the order of the day.

The palpable negative impact of the above practice on productivity, the responsiveness, legitimacy and transparency of government, the implementation of policies cannot be overemphasized. The reasons for these despicable acts are not farfetched.

Over the decades since 1966, Nigeria has evolved as an undemocratic and pseudo autocratic nation thus transforming the civil service into an institution to execute the unquestioned, will and whims of unaccountable military juntas.

Recruitment into the civil service has been influenced by patronage and politics. Nepotism and tribalism is the order of the day. Because of the political under tones entrenched in the public service people are recruited based on tribe and connections.

Unprofessional and incompetent hands are now recruited into the public service; poor salaries of the public servants are also contributing to the collapse of the Nigeria public service. The wages salaries and financial entitlements of the workers hardly over meet their needs. As a result of these the staff engages in corrupt practices which include bribery, conniving with contractors by inflating contracts and the outright leaking and sales of government information.

Lack of working implements for the public servants thus making hem idle even if they are willing to work. There are also external factors that have led to this lack of ethics and accountability in the Nigerian public service. Foreign business men and agencies have also been found to offer bribes and also help in storing of looted funds from the public service in their banks.

\section{Perspective on Bureaucratic Ethics and Corruption}

Most administrative system in African states have to undergo one reform or the other especially when such reform is expected to transform the administrative system form a mere service delivery mentality and orientation of the colonial period to a more dynamic virile and developmental one. To achieve this, the various reforms aimed at professionalizing the service. Professionalism is an over arching value that determines how the activities of the public service will be carried out.

It encompasses other values such as loyalty, neutrality, transparency, diligence; effectiveness, impartiality and such values as may be peculiar to individual countries. Agara and Olarinmoye (2009) said every member of the public service is expected to accept and imbibe these values. These shared values are what is collectively referred to as public service ethics. Ethics therefore, is at the core of professionalism and efficiency of the public service.

Davis (1990) has defied ethics as those morally permissible standards of conducts that each member of a group wants every other to follow them too. Thompson (1985) has defined administrative ethics as involving the application of moral principles to the conduct of official responsibilities and duties. Chapman (1988) on the other hand has defined civil service ethics as the application of moral standards in the course of official work.

Osoba (2000) corruption is a form of anti-social behavior by an individual or social group which confers unjust or fraudulent benefit on it perpetrators and is inconsistent with the established legal norms and 
prescribed moral ethos of the land is likely to subvert or diminish the capacity of the legitimate authorities to provide fully for the material and spiritual well being of all members of society in a just equitable manner.

\section{Government Intervention to Restor Ethics and Accountability in the Nigerian Public Service}

The Nigerian government over the decades has tried to stem this very ugly trend with the establishment of various agencies and bodies. In 1966 the public accounts committee was set up to assist the legislature in overseeing the expenditure of public funds. In 1975 the public complaints commission was set up largely because of the failure of the public account committee and the fall of the first republic. Under Murtala/Obasanjo junta, there was a massive sacking of top public servants who are found to have enriched themselves and abused their office. Today, we have agencies like civil service commission; independent corrupt practices commission (ICPC), SERVICOM and the economic and financial crimes commission (EFCC). These bodies have been empowered to investigate and prosecute all those engaged in questionable practices in Nigerian civil services. In some cases those bodies have been partially successful in achieving some of the objective of government as regards the public service.

\section{Conclusion}

Deriving from the above, it should be realized that accountability is essential for the efficient functioning of the public services especially as it is the primary and major implementation arm of government accountability acts as a quality control device for the public service and so the public as citizens and consumers in the public realm can expect to receive the best service. Accountability also underscores the superiority of the public will over private interest to those expected to serve and ensures that the public servants behave according to the ethics of their profession.

\section{Recommendation}

A common approach to reduce the level of corrupt and unethical behavior in the national public service in Nigeria.

Firstly, wide awareness on the part of public servants political officials, and the public at large of ethical values and standards in necessary are outlined in the civil service fules (CSR), anti-corruption laws, codes of conduct and the international code of conduct for public officials.

Secondly, political will and commitment to institutionalized and enforce these standards must exist. To create. Such will training within the public service as well as public promotional campaigns must be carried out.

Thirdly, working conditions for public servant including retirement, job guarantees, salaries and training among other factors are crucial with a view to reducing temptations. A cheap civil servant costs the state a lot.

Fourthly, there is a need to introduce a mechanism for consultation in order to promote participation and devise activities, and public control system.

Filthy, media and donors can encourage action against un-ethical behavior and corruption by setting pre- conditions for provision of funds.

\section{References}

Agar at. Olorinmoye (2009) "Ethics and accountability in Nigeria public service: An listorical overview" journalist public administration and pobicy research vol.1 (1) pp.011-018 
Champion R (1988) ethics in britist civil service, London, rout ledge Davis (1990) "who can teach work place ethics? Teaching philosophy federal republic of Nigeria, Revised financial regulations, govt. printer, Lagos 2001.

Federal republic of Nigeria, civil, civil service rules, government printer, Lagos, 2001.

Osoba S.O (2000), "corruption in Nigeria: Historical perspectives in Rwekaza Mukandala (Ed): African Public Administration: A reader, Harare AAPS Books.

Thompson DF (185) “The possibility of administrative ethics”, public administrative review, September/October. 